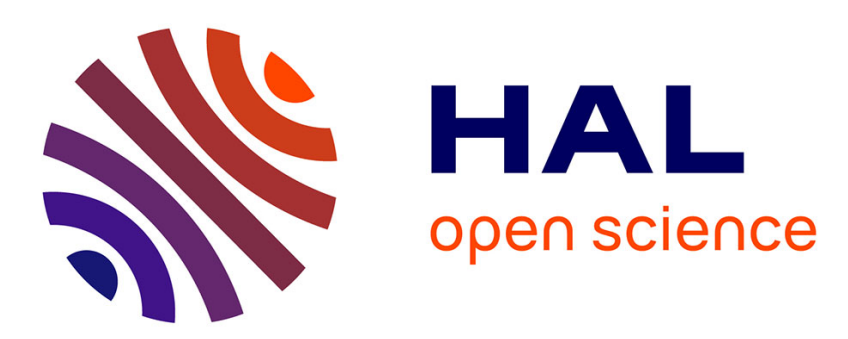

\title{
Spontaneous remissions in breast cancer underline the need of more evidence: screening should not detect more cancer but earlier cancer
}

Franz Porzsolt, Dieter Hölzel

\section{- To cite this version:}

Franz Porzsolt, Dieter Hölzel. Spontaneous remissions in breast cancer underline the need of more evidence: screening should not detect more cancer but earlier cancer. Journal of Public Health, 2009, 18 (1), pp.15-19. 10.1007/s10389-009-0275-4 . hal-00535285

\section{HAL Id: hal-00535285 \\ https://hal.science/hal-00535285}

Submitted on 11 Nov 2010

HAL is a multi-disciplinary open access archive for the deposit and dissemination of scientific research documents, whether they are published or not. The documents may come from teaching and research institutions in France or abroad, or from public or private research centers.
L'archive ouverte pluridisciplinaire HAL, est destinée au dépôt et à la diffusion de documents scientifiques de niveau recherche, publiés ou non, émanant des établissements d'enseignement et de recherche français ou étrangers, des laboratoires publics ou privés. 


\title{
Spontaneous remissions in breast cancer underline the need of more evidence: screening should not detect more cancer but earlier cancer
}

\author{
Franz Porzsolt • Dieter Hölzel
}

Received: 11 November 2008 / Accepted: 8 April 2009/Published online: 1 September 2009

(C) Springer-Verlag 2009

\begin{abstract}
Aim Analysis of the hypothesis that 22\% of breast cancer cases detected by screening mammography would disappear spontaneously.

Methods Critical appraisal of the relevant scientific literature using established methods.

Results The hypothesis - although it is unusual-seems to be very well supported by data from several independent research groups and justifies three lessons.

Conclusions First, it is necessary to complete the last step of the concept of traditional evidence-based medicine (EBM), i.e., to confirm that the outcome that is predicted by scientific evidence will also be observed in daily clinical practice. Second, the focus of medical teaching should be directed to final clinical outcomes and patient benefit rather than surrogate parameters, such as completed procedures or test results. Third, the availability of data to answer unsolved questions may become a more important indicator for high-quality health-care systems than the performance of services of unknown incremental value.
\end{abstract}

Keywords Spontaneous remissions · Breast cancer . Mammography

The project was neither supported by grants nor were there any conflicts of interest.

\section{F. Porzsolt $(\square)$}

Clinical Economics, University of Ulm,

Frauensteige 6,

89073 Ulm, Germany

e-mail: franz.porzsolt@uniklinik-ulm.de

D. Hölzel

Munich Cancer Registry (MCR), University of Munich,

Marchioninistraße 15,

81377 Munich, Germany

\section{Introduction}

Norwegian epidemiologists (Zahl et al. 2008) presented a study that is different from classical evidence-based studies: it is neither randomized nor is it presenting a better test or treatment. This study seriously challenges what we know about breast cancer. It questions our concept on the natural course of the disease, the effectiveness of breast cancer screening as well as of breast cancer therapy. If the result of this study is confirmed, it may be considered one of the first examples of 'confirmation-based medicine.' The authors of this pivotal study assume that $22 \%$ of breast cancer cases will regress spontaneously (Zahl et al. 2008).

\section{Several steps are necessary to make progress}

Several challenging steps were necessary to phrase the final hypothesis that a considerable portion of breast cancer cases might regress spontaneously. This final hypothesis was triggered by a simple but critical question Zahl and his colleagues asked. They concluded that the high compliance with breast cancer screening in Norway and Sweden (about $80 \%$ ) should result in an increased breast cancer incidence rate. Second, the increased incidence rate of breast cancer in younger women should be accompanied by a corresponding decrease of breast cancer incidence in elderly women. This second hypothesis is the really important part of the considerations.

As Zahl and his colleagues could not confirm the second hypothesis, they postulated in their 2004 papers that "the level of overdiagnosis in nationwide mammography screening is much higher than previously thought" (Zahl et al. 2004b). Swedish scientists reported data similar to those of Zahl et al., but derived a different interpretation. They 
concluded that their previous interpretation (Jonssone et al. 2005) on a long-term reduction of breast cancer mortality by $26-30 \%$ was confirmed by the actual results (Jonsson et al. 2007). When reanalysing Jonsson's data (Jonsson et al. 2005), Zahl and Maehlen (2006) concluded that $73 \%$ of the "latent cancers" are no longer detectable at the mammograms of women at age 70. Zahl and Mæhlen published the hypothesis that some of these latent cancers may regress spontaneously already in 2004 (Zahl et al. 2004a). Later on they described the incidence rates of breast cancer of two groups of women ages 50 to 64 in two overlapping 6-year periods (Zahl et al. 2008). One group of 109,784 women was followed from 1992 to 1997. Mammography screening in Norway was initiated in 1996. In 1996 and 1997, all women of this group were offered a single mammogram within this 2-year period, and about $80 \%$ accepted. The second group of 119,472 women was followed from 1996 to 2001. All were offered mammograms every 2 nd year in this 6-year period, i.e., three mammograms, and about $80 \%$ accepted. It was expected that the two groups would have roughly the same number of breast cancers, either detected at the end or found along the way. Instead, $22 \%$ more cancers were detected in women who had routine screenings every 2 nd year (Table 1 ). The most important possible pitfalls of this comparison of non-randomized cohorts were discussed and, for example, the magnitude of differential use of hormone replacement therapy was calculated. The comparison is fair. Not this observation, but its interpretation was revolutionary: these additional cancers will not affect the women's life if neglected. As this "new idea" absolutely contradicts the present understanding of cancer biology, most clinicians will reject it. There are two additional steps that have to be completed before this potential scientific progress can be transferred from bench to bedside.

First, scientific reports that contradict the "state of the art" have to convince referees and editors of scientific journals as there will be no progress without publication. According to a "biologic law", papers that contradict mainstream thinking have a higher chance to be rejected by referees and editors than those that agree. Our previous editorial (Porzsolt et al. $2003 a, b)$ pointed out that the acceptance or rejection of scientific evidence is a "subjective" decision. There are not many examples to support this "biologic law": an earlier report of Zahl et al. was withdrawn from one journal (2006a) and subsequently published in another (2006b). When we (Kaplan and Porzsolt 2008) scrutinized the actual publication of Zahl (2008), we concluded that there are more data that corroborate than contradict this hypothesis.

- There are data from randomized studies on mammographies that confirm Zahl's hypothesis (Miller et al. 1992, 2000, 2002; Zackrisson et al. 2006).

- It can clearly be demonstrated that some breast cancer patients benefit from treatment, but the proportion of breast cancer patients who survive for unknown reasons is much bigger than the proportion in whom survival is clearly related to the treatment. The recent results of the Early Breast Cancer Trialists' Collaborative Group (EBCTGC 2008) confirmed that systemic treatment reduces the 10-year breast cancer mortality from $32 \%$ to $24 \%$ in women younger than 50 years and from $42 \%$ to $36 \%$ in women $50-69$ years. These numbers include three important messages: About $30 \%$ of all women with detected breast cancer will die despite of treatment. Almost $10 \%$ of treated women ( $8 \%$ of younger women and $6 \%$ of women $50-69$ years of age) benefit from systemic treatment, and finally, $60 \%$ of women with breast cancer will survive without systemic treatment. There are no valid estimates on the proportion of breast cancer patients who survive due to local treatment such as surgery.

- Spontaneous remissions are known in many tumours such as metastatic melanoma and renal cell cancer, in neuroblastoma and in precancerous lesions of colon and cervix cancer (for examples, see Zahl et al. 2008).

- Zahl et al. (2008) could demonstrate that the difference between the experimental and the control group in their study was neither related to an improved quality of the Norwegian cancer registry, nor to differences between the experimental and the control group, nor to an improving sensitivity of mammography, nor to a temporal increase in the incidence caused by external factors such as hormone replacement therapy, and finally,

- in contrast, Zahl's results may even underestimate the spontaneous remission rates as opportunistic screening could not be avoided in the control group, and the compliance with the screening program was $80 \%$, but not $100 \%$ in the experimental group.

Table 1 Six-year incidence of breast cancer in women age 50-69 (cases per 100,000) in the screened group and control group (Zahl et al. 2008)

\begin{tabular}{lllll}
\hline $\begin{array}{l}\text { Age at beginning } \\
\text { of the study }\end{array}$ & $\begin{array}{l}\text { Age at end } \\
\text { of the study }\end{array}$ & $\begin{array}{l}\text { Screened group: Mammograms } \\
\text { every 2nd year over 6-year period }\end{array}$ & $\begin{array}{l}\text { Control group: One mammogram } \\
\text { at end of 6-year period }\end{array}$ & $\begin{array}{l}\text { Relative risk } \\
\text { screened/control }\end{array}$ \\
\hline $50-64$ & $55-69$ & 1,909 & 1,564 & $1.22(1.16-1.30)$ \\
\hline
\end{tabular}


Second, it is not sufficient to convince the referees and editors of a scientific journal, but the scientific community has to accept the new concept. There are several examples that demonstrate that it takes about a decade to translate an innovation from bench to bedside. We showed for testicular cancer that the delayed use of cisplatin for more than 10 years may have resulted in more then 1,000 avoidable deaths (Hölzel and Altwein 1991).

Third, once a statement or a guideline has been accepted by the scientific community, it is essential that scientists keep reanalyzing this 'state of the art'. New knowledge may emerge and may challenge a traditional statement or guideline. The performance indicator no. 14 of the European guidelines for quality assurance in breast cancer screening and diagnosis (Perry et al. 2006) requests that the breast cancer detection rate, expressed as a multiple of the underlying, expected breast cancer incidence rate (IR) in the absence of screening should be 1.5 -fold of the IR in subsequent regular screening examinations. This requirement is probably based on the assumption that any additionally detected cancer will be associated with benefit for the patient. In the context of the new data, this conclusion may be reanalysed. The new version of the European guideline may request that screening should not detect more cancer, but the existing cancer earlier.

\section{Progress to whom}

There are several natural hurdles that prevent the acceptance of a new idea by the general population. Doctors who provide a particular service, industries that produce the needed products, insurance companies that offer a particular service and politicians who are expected to guarantee the best possible health care will have considerable difficulties to change from the traditional concept to the new idea. The same will happen to affected women.

Mammography is probably the most frequently used and the most investigated of all screening methods. According to the actual state of the art, mammography is recommended by medical societies and politicians and is strongly demanded by women (Schwartz et al. 2004) despite of the known rates of false-positive and false-negative test results and the high number of persons needed to screen $(1,000$ $2,000)$ to prevent one death due to breast cancer (Gøtzsche and Nielsen 2006).

The real problem with screening is the appraisal rather than the assessment: The effect of screening is not a random effect, but is statistically significant. In absolute numbers almost 1 per mille of womens' lifes can be saved by screening. The problem is the appraisal of this value of screening. Most women believe the political message that says that breast cancer screening would reduce breast cancer mortality by $20 \%$. The scientific message is that the relative but not the absolute risk reduction is $20 \%$. Nobody knows if women will continue to demand breast cancer screening and how many societies will be willing to pay for breast cancer screening if they know that the true effect of screening is less than $1 \%$ instead of $20 \%$. There will be a tremendous discussion when it is realized that breast cancer screening is the most investigated screening method and is probably better supported by scientific evidence than any other screening in adult medicine.

Possible explanations for this strong demand may be related to 'perceived safety', which is highly dependent on the provided information. We discussed this concept of 'perceived safety' in breast cancer patients (Porzsolt et al. 2006b) and are aware that the concept of perceived safety may be risky if it keeps patients from using effective treatments. But it may be helpful if perceived safety

Table 2 Goals, methods and results of traditional evidence-based medicine (EBM) and the proposed confirmation-based medicine

\begin{tabular}{|c|c|c|}
\hline & Evidence-based medicine & Confirmation-based medicine \\
\hline Goals & $\begin{array}{l}\text { Comparison of new and established therapies under conditions of } \\
\text { a clinical study (comparison of efficacy). Consideration of } \\
\text { internal validity. Results presented from the viewpoint of } \\
\text { clinical epidemiology }\end{array}$ & $\begin{array}{l}\text { Comparison of new and established therapies under everyday } \\
\text { conditions (comparison of effectiveness). Consideration of } \\
\text { external validity. Results presented from the viewpoints of } \\
\text { different stakeholders }\end{array}$ \\
\hline \multirow[t]{3}{*}{ Methods } & $\begin{array}{l}\text { Step 1: Definition of characteristics of the study groups (inclusion } \\
\text { and exclusion criteria). Definition of treatment options }\end{array}$ & $\begin{array}{l}\text { Step 1: Patients allocated to different treatment groups } \\
\text { according to preference. All patients are included }\end{array}$ \\
\hline & Step 2: Random allocation of individual patients to treatment options & $\begin{array}{l}\text { Step 2: Definition of characteristics of study groups and } \\
\text { consideration of treatment options }\end{array}$ \\
\hline & $\begin{array}{l}\text { Step 3: Evaluation of patients in the groups to which they were } \\
\text { randomized (intention to treat) }\end{array}$ & $\begin{array}{l}\text { Step 3: Classification of patients for evaluation in the } \\
\text { subgroups according to defined criteria and treatment option }\end{array}$ \\
\hline Results & $\begin{array}{l}\text { Comparison of new and established therapies under ideal } \\
\text { conditions. Confirmation of internal validity Requirement for } \\
\text { planning and conduct of health-care research }\end{array}$ & $\begin{array}{l}\text { Testing of results of clinical research under everyday } \\
\text { conditions. Description of external validity. Consideration } \\
\text { of perspectives of different stakeholders }\end{array}$ \\
\hline
\end{tabular}


contributes to managing psychological problems. The political problem is expressed by the dissonance of the political recommendation (to screen and to treat) and the misunderstanding of the scientific message.

\section{Open questions}

The message of science is not to avoid screening and treatment, but rather to keep investigating it in order to remove the remaining uncertainty. We also need reliable data on which women will benefit and which will be harmed by breast cancer screening and treatment. This challenge can be called "confirmation-based medicine (CBM)" and corresponds to the last step of the traditional evidence-based medicine concept proposed by David Sackett and colleagues (2004). From a different point of view, one can argue this last step bridges evidence-based medicine and the developing health-care research (Hay 1999; Porzsolt and Kilian 2006). Differences between evidence-based medicine and "confirmation-based medicine" (Table 2) may be expressed by differences in goals, methods and results as proposed earlier (Porzsolt et al. 2005; 2006b).

For breast cancer management these data can be generated in two ways. First, we should try to convince all eligible women that only a high participation rate will generate the data that are needed for the best possible management. Nevertheless, there will be women who will reject mammography screening for various reasons. In order to minimize the negative effects of non-compliance, we might discuss the anonymous recording of risk factors of any non-compliant woman at a national data base. If this collection of information is acceptable from an ethical point of view, one could improve the quality of screening data by comparing the baseline risks of compliant and noncompliant women (Porzsolt 2009).

Second, we have to study appropriate markers that can widely be applied to identify the subgroups of patients that will benefit from screening and treatment. Examples of these markers are described by van de Vijver et al. (2002), Ghosh et al. (2008) and Harbeck et al. (2008). In Germany, breast cancer screening began to be offered to the public at the end of the 1960s. Today we spend $€ 250-300$ million annually for breast cancer screening. Unfortunately, the German contribution to the scientific progress in breast cancer management is rather small. Also, this aspect deserves reconsideration.

Finally, there are three lesions we can learn from the Zahl experiment (Zahl et al. 2008). First, there is a need to extend the concept of traditional evidence-based medicine (EBM). The renewed aspect may be named outcomes research or confirmation-based medicine $(\mathrm{CBM})$. The traditional form of EBM requested scientific evidence to support the introduction of a new diagnostic tool or treatment into day-to-day practice. The large mammography trials completed in the period of 1960-1990 are examples of EBM that justified the introduction of mammography screening. The Zahl experiment is an example of outcomes research or CBM: it tries to confirm in day-to-day practice that has been recommended by EBM. EBM was the first of two necessary steps. It was the evidence-based recommendation to introduce an innovation. CBM represents the continuation of these steps. It is the evidence-based confirmation that the innovation is really doing what it promised to do.

Second, we might teach our students the principles of outcomes research in addition to the principles of EBM. Similar objective procedures were introduced by the Japanese Bank of International Cooperation (JBIC) for Confirmation of Environmental and Social Considerations to ensure its compliance with guidelines (Japan Finance Cooperation 2003). We tried to offer such a strategy in medicine that we called 'clinical economics'. Both outcomes research and 'clinical economics' follow the same strategy. They are concerned about the value of medicine from the patients' point of view. This strategy may become an important topic in medical schools (Porzsolt and Kilian 2006).

Third, the ability of a health-care system to provide the data that are needed to answer questions like those raised by Zahl et al. may, in the future, be considered an important indicator for the quality of a national health-care system.

Conflict of Interest The authors confirm that there are no relevant associations that might pose a conflict of interest.

\section{References}

Early Breast Cancer Trialists' Collaborative Group (EBCTCG), Clarke M, Coates AS, Darby SC, Davies C, Gelber RD, Godwin J, Goldhirsch A, Gray R, Peto R, Pritchard KI, Wood WC (2008) Adjuvant chemotherapy in oestrogen-receptor-poor breast cancer: patient-level meta-analysis of randomised trials. Lancet 371:29-40

Ghosh K, Brandt KR, Sellers TA, Reynolds C, Scott CG, Maloney SD, Carston MJ, Pankratz VS, Vachon CM (2008) Association of mammographic density with the pathology of subsequent breast cancer among postmenopausal women. Cancer Epidemiol Biomarkers Prev 17:872-879

Gøtzsche PC, Nielsen M (2006) Screening for breast cancer with mammography. Cochrane Database Syst Rev (4):CD001877. Review

Harbeck N, Nimmrich I, Hartmann A, Ross JS, Cufer T, Grützmann R, Kristiansen G, Paradiso A, Hartmann O, Margossian A, Martens J, Schwope I, Lukas A, Müller V, Milde-Langosch K, Nährig J, Foekens J, Maier S, Schmitt M, Lesche R (2008) Multicenter study using paraffin-embedded tumor tissue testing PITX2 DNA methylation as a marker for outcome prediction in 
tamoxifen-treated, node-negative breast cancer patients. J Clin Oncol Aug 18. [Epub ahead of print]

Hay J (1999) Health care costs and outcomes: How should we evaluate real world data Value in Health 2: 417-419

Hölzel D, Altwein J (1991) Hodentumoren: Ist der Rückgang der Mortalität in der Bundesrepublik Deutschland zu langsam erfolgt? Dtsch Arztebl 88:4123

Japan Finance Cooperation and Japan Bank of International Cooperation (2003) Summary of Objection Procedures Based on Guidelines for Confirmation of Environmental and Social Considerations. http:/www.jbic.go.jp/en/about/environment/ guideline/disagree/index.html

Jonsson H, Johansson R, Lenner P (2005) Increased incidence of invasive breast cancer after the introduction of service screening with mammography in Sweden. Int J Cancer 117:842-847

Jonsson H, Bordás P, Wallin H, Nyström L, Lenner P (2007) Service screening with mammography in Northern Sweden: effects on breast cancer mortality - an update. J Med Screen 14:87-93

Kaplan RM, Porzsolt F (2008) The natural history of breast cancer. Arch Intern Med 168:2302-2303

Miller AB, Baines CJ, To T, Wall C (1992) Canadian National Breast Screening Study 2. Breast cancer detection and death rates among women aged 50 to 59 years. CMAJ 147:1477-1488

Miller AB, To T, Baines CJ, Wall C (2000) National Breast Screening Study-2: 13-year results of a randomized trial in women aged 50 59 years. J Natl Cancer Inst 92:1490-1499

Miller AB, To T, Baines CJ, Wall C (2002) The Canadian National Breast Screening Study-1: breast cancer mortality after 11 to 16 years of follow-up. A randomized screening trial of mammography in women age 40 to 49 years. Ann Intern Med 137:305-312

Perry N, Broeders M, deWolf C, Törnberg S, Holland R, von Karsa L (2006) European guidelines for quality assurance in breast cancer screening and diagnosis. 4th edition. European Communities 2006. ISBN 92-79-01258-4

Porzsolt F (2009) Der natürliche Verlauf des Mammkarzinoms. Dtsch Med Wochenschr 134:238

Porzsolt F, Kaplan RM (2006) "CLINECS"-Strategy and tactics to provide evidence of the usefulness of health care services from the patient's standpoint (value for patients). In: Porzsolt F, Kaplan RM (eds) Optimizing health-improving the value of health care delivery. Springer, New York

Porzsolt F, Kilian R (2006) Klinische Forschung, Ergebnisforschung, Versorgungsforschung. Gesundh ökon Qual manag 11:311-318

Porzsolt F, Ohletz A, Thim A, Gardner D, Ruatti H, Meier H, SchlotzGorton N, Schrott L (2003a) Evidence-based decision making. The six step approach. Editorial. ACP-Journal Club 139:A10
Porzsolt F, Ohletz A, Thim A, Gardner D, Ruatti H, Meier H, SchlotzGorton N, Schrott L (2003b) Evidence-based decision making. The six step approach. Editorial. Evidence-Based Medicine $8: 165-166$

Porzsolt F, Stengel D, Ghosh A (2005) Ergebnisforschung: Nutzen für Patienten muss nachgewiesen werden. Deutsches Ärzteblatt 102:2380-2385

Porzsolt F, Leonhardt-Huober H, Kaplan RM (2006a) Aims and value of screening: is perceived safety a value for which to pay? In: Porzsolt F, Kaplan RM (eds) Optimizing health - improving the value of healthcare delivery. Springer, New York, pp 199-204

Porzsolt F, Stengel D, Ghosh AK, Kaplan RM (2006b) Clinical research and outcomes research: Common criteria and differences. In: Porzsolt F, Kaplan RM (eds) Optimizing health-improving the value of healthcare delivery. Springer, New York, pp 257-264

Sackett DL, Straus SE, Richardson WS et al (2004) Evidence-based medicine. How to practice and teach EBM, 2nd ed., Churchill Livingstone, Edinburgh

Schwartz LM, Woloshin S, Fowler FJ Jr, Welch HG (2004) Enthusiasm for cancer screening in the United States. JAMA 291:71-78

van de Vijver MJ et al (2002) A gene-expression signature as a predictor of survival in breast cancer. N Engl J Med 347:1999-2009

Zackrisson S, Andersson I, Janzon L, Manjer J, Garne JP (2006) Rate of over-diagnosis of breast cancer 15 years after end of Malmö mammographic screening trial: follow-up study. BMJ 332:689-692

Zahl PH, Mæhlen J (2006) Do model results suggest spontaneous regression of breast cancer? Int J Cancer 118:2647

Zahl PH, Andersen JM, Mæhlen J (2004a) Spontaneous regression of cancerous tumors detected by mammography screening. JAMA 292:2579-2580

Zahl PH, Strand BH, Mæhlen J (2004b) Incidence of breast cancer in Norway and Sweden during introduction of nationwide screening: prospective cohort study. BMJ 328:921-924

Zahl PH, Gøtzsche PC, Andersen JM, Mæhlen J (2006a) WITHDRAWN: Results of the Two-County Trial of mammography screening are not compatible with contemporaneous official Swedish breast cancer statistics. Eur J Cancer Mar 9. [Epub ahead of print]

Zahl PH, Gøtzsche PC, Andersen JM, Maehlen J (2006b) Results of the Two-County trial of mammography screening are not compatible with contemporaneous official Swedish breast cancer statistics. Dan Med Bull 53:438-440

Zahl PH, Mæhlen J, Welch HG (2008) The natural course of invasive breast cancer detected by mammography. Arch Intern Med $168: 2311-2316$ 